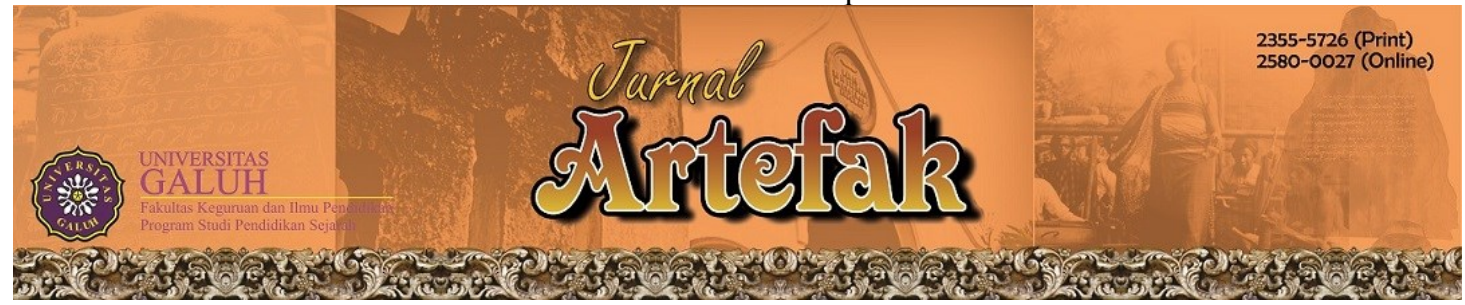

https://jurnal.unigal.ac.id/index.php/artefak/article/view/5555

\title{
PERAN STRATEGIS NAHDLATUL ULAMA DALAM PENGUATAN NASIONALISME KEMANUSIAAN UNTUK MENANGKAL RADIKALISME
}

\author{
Abdul Rahman ${ }^{1}$, Ahmadin $^{2}$, Rifal $^{3}$ \\ 1,2,3 Universitas Negeri Makassar, Indonesia ${ }^{1}$ \\ E-mail: abdul.rahman8304@unm.ac.id ${ }^{1}$, ahmadin12@gmail.com ${ }^{2}$, rifal12@gmail.com3 \\ Sejarah Artikel:Diterima 15 Juli 2021, Disetujui: 27 Agustus 2021, Dipublikasikan: 30 September 2021
}

\begin{abstract}
Abstrak
Tulisan ini bertujuan untuk mendeskripsikan peran Nahdlatul Ulama (NU) dalam menangkal radikalisme di Indonesia melalui penguatan nasionalisme kemanusiaan. Tujuan tesebut dijabarkan dalam tiga permasalahan pokok yaitu: bagaimana konsep nasionalisme kemanusiaan yang dikembangkan oleh NU, bagaimana upaya NU dalam mewujudkan nasionalisme kemanusiaan, dan bagaimana cara NU mengimplementasikan nasionalisme kemanusiaan dalam kehidupan berbangsa dan bernegara. Penelitian ini menggunakan metode sejarah yaitu: pemilihan topik, heuristik, kritik, interpretasi dan historiografi. Hasil penelitian menunjukkan bahwa nasionalisme kemanusiaan yang dikembangkan oleh NU ialah paham kebangsaan yang memberikan pengakuan kepada seluruh elemen bangsa yang terdiri atas suku, agama, ras, dan antar golongan yang berbeda untuk berpartisipasi aktif dalam melaksanakan hak dan kewajiban berdasarkan Pancasila. Nasionalisme kemanusiaan diwujudkan melalui kegiatan dakwah dan pendidikan untuk menghasilkan sumber daya manusia yang unggul dalam meneguhkan dan menyebarkan pemahaman aswaja sebagai pilar penguatan adpatasi, integrasi, pencapaian tujuan dan pemeliharaan tatanan sebagai bangsa yang berdaulat. Dalam mengimplementasikan nasionalisme kemanusiaan, NU menerapakan prinsip dasar yaitu tawazun (keseimbangan), tasamuh (toleran), tawasut (moderat), dan i'tidal (adil) dalam berbagai sektor kehidupan berbangsa dan bernegara.
\end{abstract}

Kata kunci: Nahdalatul Ulama, Nasionalisme Kemanusiaan, Radikalisme

\begin{abstract}
This paper aims to describe the role of Nahdlatul Ulama (NU) in counteracting radicalism in Indonesia through strengthening humanitarian nationalism. These objectives are described in three main problems, namely: how is the concept of humanitarian nationalism developed by NU, how NU's efforts to realize humanitarian nationalism, and how NU implements humanitarian nationalism in the life of the nation and state. This study uses historical methods, namely: topic selection, heuristics, criticism, interpretation and historiography. The results show that the humanitarian nationalism developed by NU is a nationalism that gives recognition to all elements of the nation consisting of ethnicity, religion, race, and between different groups to actively participate in exercising rights and obligations based on Pancasila. Humanitarian nationalism is manifested through preaching and education activities to produce superior human resources in strengthening and spreading the understanding of aswaja as pillars of strengthening adaptation, integration, achieving goals and maintaining order as a sovereign nation. In implementing humanitarian nationalism, NU applies the basic principles of tawazun (balance), tasamuh (tolerant), tawasut (moderate), and i'tidal (fair) in various sectors of the life of the nation and state.
\end{abstract}

Keywords: Nahdlatul Ulama, Humanitarian Nationalism, Radicalism 


\section{PENDAHULUAN}

Kehadiran Negara Kesatuan Republik Indonesia merupakan kesepakatan dan kesukarelaan dari berbagai suku bangsa dan agama. Masyarakat yang berbeda berdasarkan suku, agama, ras dan antar golongan kemudian bersatu padu untuk mendirikan negara Republik Indonesia yang secara resmi diproklamasikan pada tanggal 17 Agustus 1945 sebagai negara berdaulat dan merdeka. Proklamasi kemerdekaan begitu penting artinya untuk mendapatkan pengakuan dari negara lain, sekaligus sebagai bukti kebulatan tekad untuk membangun negara yang dicita-citakan bersama berdasarkan Pancasila dan Pembukaan UUD 1945.

Sejak proklamasi kemerdekaan, Indonesia telah mengalami fase perjalanan era pemerintahan yaitu Orde Lama, Orde Baru, dan Era Reformasi. Era reformasi lazim pula dikenal dengan istilah zaman transisi demokrasi, yaitu zaman ketika suatu rezim otoriter berakhir dan diganti oleh rezim demokratis (Huntington, 1996). Era otoriter di Indonesia dilabelkan pada masa pemerintahan Orde Baru, meskipun tidak seluruh aspek kekuasaan pemerintahan Orde Baru mencerminkan nuansa otoritarian (Sarman, 2018). Orde Baru digambarkan sebagai rezim diktator yang diwarnai oleh kebijakan politik yang represif, pemerintahan yang tidak bersih dari praktik korupsi, kolusi, dan nepotisme. Kondisi objektif tersebut menjadi faktor pendorong timbulnya gerakan reformasi yang berhasil menghantarkan Soeharto berhenti sebagai Presiden Republik Indonesia pada Hari Kamis 21 Mei 1998.

Memasuki era reformasi, Indonesia berada pada posisi transisi menuju demokrasi. Secara teoritik transisi demokrasi ditandai oleh dua kecenderungan yaitu pembentukan panggung politik baru oleh kelompok lama dan tampilnya nilai-nilai baru yang diusung oleh kekuatan politik baru. Namun dalam konteks jagad politik Indonesia, era transisi ditandai pula dengan kemunculan aktor baru yang dikenal sebagai gerakan Islam Baru. Kehadiran aktor tesebut tidak dapat dipisahkan dengan pergerakan dan kebangkitan Islam di Timur Tengah yang terdiri atas tiga poros yaitu Poros Revolusi Islam Iran 1979, Poros Ikhwanul Muslimin, dan Poros Wahabi/Salafi (Rahmat, 2018). Kebangkitan pergerakan Islam dari tiga poros tersebut menjadi cikal bakal kelahiran kelompok gerakan Islam Politik di Indonesia misalnya Hizbut Tahrir Indonesia, Front Pembela Islam, Majelis Mujahidin Indonesia, dan kelompok tarbiyah yang menjelma menjadi Partai Keadilan Sejahtera.

Perkembangan Islam politik pada awal reformasi sangat kuat sehingga mereka memiliki kepercayaan diri untuk menjadikan Indonesia sebagai negara Islam/negara khilafah (Joebagio, 2016). Perjuangan untuk mencapai tujuan itu seringkali dibarengi dengan aksi-aksi kekerasan dengan mengabaikan prinsip toleransi yang justru bertentangan dengan demokrasi sebagai tujuan dasar reformasi. Kelompok Islam politik menghendaki agar kehidupan pribadi maupun praktik penyelenggaraan negara didasarkan pada sistem Islam serta menolak segala bentuk ideologi yang berasal dari Barat yakni demokrasi, liberalisasi, dan sekularisasi. Selain itu, watak keberagamaan kelompok Islam politik cenderung selalu curiga terhadap kaum non-Muslim. Mereka selalu menaruh curiga akan munculnya kristenisasi, pemurtadan, dan pendangkalan aqidah (Karim, 2012). Pergerakan mereka mencapai puncaknya ketika munculnya aksi 212 yang menuntut Basuki Tjahaya Purnama untuk diproses hukum karena telah menghina dan melecehkan kitab suci al-Quran.

Maraknya aksi-aksi intoleran yang bernuansa kekerasan dari kalangan Islam politik menjadi kegusaran Nahdlatul Ulama (NU). Aksi-aksi kekerasan dinilai dapat merusak tatananan kebangsaan yang didalamnya terjalin sebuah cita-cita untuk menjadikan Indonesia sebagai rumah bersama dengan mengabaikan diferensiasi sosial yang didasarkan atas suku, agama, ras, dan antargolongan. Fenomena tersebut membangkitkan semangat dalam menyelamatkan NKRI dan Pancasila berdasarkan prinsip nasionalisme kemanusiaan. Keaktifan NU dalam menjaga keutuhan NKRI sejak zaman Orde Lama hingga saat ini kemudian dinilai sebagai upaya NU untuk dekat dengan penguasa demi memperoleh posisi strategis dalam lingkaran kekuasaan (Masruhan, 2009). Atas dasar hal itu, maka artikel ini menjelaskan tentang motif NU dalam menggagas, memperjuangkan, dan membumikan nasionalisme kemanusiaan. 


\section{METODE PENELITIAN}

Sebagai upaya dalam membahas masalah dalam penelitian ini, maka dipilih jenis penelitian kualitatif. Berdasarkan objek penelitian yang berfokus pada masa silam, maka penelitian ini menggunakan metode sejarah yang terdiri atas lima tahap sebagaimana yang dikemukakan oleh Kuntowijoyo yaitu pemilihan topik, heuristik, kritik, interpretasi, dan historiografi (Kuntowijoyo, 2005). Pemilihan topik didasarkan pada kedekatan emosional dan intelektual. Emosional karena penulis sangat kagum dengan cara-cara NU dalam menyebarkan Islam dan kebangsaan yang moderat. Sedangkan kedekatan intelektual, karena penulis merupakan pemerhati sejarah yang berkaitan dengan Islam dan Kenegaraan. Heuristik dilakukan dengan cara mengumpulkan sumber pustaka yang berkaitan dengan topik penelitian berupa buku, jurnal, dan media massa baik yang online maupun offline. Kritik sumber yang berkaitan dengan artikel ini dilakukan secara internal maupun eksternal agar dapat memperoleh otensitas dan kredibilitas sumber. Selanjutnya, data atau informasi yang telah terkumpul diberi interpretasi, analisis, dan sintesis. Data yang telah disintesis selanjutnya dituangkan dalam bentuk narasi historis (historiografi) berupa artikel.

\section{HASIL PENELITIAN DAN PEMBAHASAN}

\section{Konsep Nasionalisme Kemanusiaan}

Kebangsaan atau nasionalisme merupakan landasan ideologis bagi keberadaan komunitas politik dalam menegakkan kedaulatan rakyat atas dasar kemanusiaan (Setialaksana, 2017). Kedaulatan rakyat merupakan wujud nyata keterlibatan masyarakat umum dalam kehidupan bernegara. Adanya kesempatan dalam melakukan partisipasi umum secara efektif merupakan wujud sebenaranya dari kebebasan dan kemerdekaan. Kemerdekaan yang berhasil diraih oleh Bangsa Indonesia merupakan puncak perjuangan (Kusmayadi, 2017) sekaligus momentum penting dalam menyatukan keberagaman sekaligus perwujudan cita-cita dalam mendirikan negara dan bangsa yang berdaulat. Akan tetapi kemerdekaan yang telah diproklamasikan masih mendapat tantangan berat, terutama dari pihak Belanda dan sekutunya. Mereka tetap berusaha untuk menanamkan kekuasaannya di Indonesia. Kondisi tersebut membuat rakyat Indonesia berusaha sekuat tenaga melakukan perjuangan baik secara diplomasi maupun perlawanan fisik.

Perlawanan rakyat Indonesia terhadap Belanda dan sekutunya dalam mempertahankan kemerdekaan merupakan bukti kekokohan rasa nasionalisme yang dimiliki. Nasionalisme yang menggelora di kalangan rakyat Indonesia tidak dapat dilepaskan dari peran utama NU. Rasa nasionalisme mencapai titik puncaknya setelah ulama utama NU menfatwakan resolusi jihad pada tanggal 22 Oktober 1945 yang pada intinya menyatakan bahwa merupakan suatu kewajiban bagi mereka yang sudah aqil baligh untuk ikut membela dan mempertahankan kemerdekaan (Saputra, 2019). Perjuangan fisik bukan hanya dilakukan oleh kalangan tentara, tetapi juga menyulut semangat kalangan santri yang tergabung dalang laskar Hizbullah dan Sabilillah.

Memasuki alam kemerdekaan, semangat nasionalisme terus digelorakan oleh NU. Bagi NU, fondasi utama keberlanjutan Indonesia sebagai bangsa yang berdaulat ialah gerakan nasionalis yang religius. NU terus mengupayakan terwujudnya sintesis antara nalar politik Islam dan kebangsaan. Pada masa awal kemerdekaan, NU menghendaki agar Indonesia berbentuk sebagai Negara Islam. Akan tetapi, ketika perjuangan memasukkan Islam sebagai dasar negara tidak berhasil dalam sidang konstituante, NU tetap terlibat dalam komponen pemerintahan. NU kemudian menegaskan bahwa tidak ada lagi keinginan untuk mendirikan negara Islam, tetapi menghendaki sebuah negara Pancasila yang rakyatnya menjalankan syariat (Saputra, 2019). Nasionalisme Indonesia yang mewujud sebagai negara-bangsa dan menggunakan sistem demokrasi dalam aktivitas politik memiliki kesepadanan dengan Islam selama tidak melanggar aturan dan doktrin yang telah ditetapkan dalam agama (Musa, 2014).

Ikhtiar NU dalam mensintesiskan antara Islam dan kebangsaan terus berlanjut pada masa Orde Baru. Sikap tersebut 
dibuktikan dengan diterimanya Pancasila sebagai asas tunggal oleh NU. Penerimaan Pancasila sebagai asas tunggal merupakan penegasan bahwa paham kebangsaan yang dikembangkan oleh NU pada masa Orde Baru ialah nasionalisme yang bersifat kultural, yakni nasionalisme yang menghargai perbedaan agama, tradisi, dan warisan budaya nusantara yang ada pada setiap daerah di Indonesia. Nasionalisme kultural yang berlandaskan pada Pancasila bertujuan untuk mempererat persatuan dan kesatuan dengan mengabaikan perbedaan agama, suku, adat istiadat, dan ras sebagai kekuatan yang dapat digunakan untuk membendung ancaman dari luar. Dalam perspektif nasionalisme kultural, lokalitas ditempatkan pada posisi terhormat. Sikap tersebut merupakan perwujudan jiwa kebangsaan NU yang mengacu pada kekayaan sejarah dan budaya Nusantara.

Memasuki era reformasi, nasionalisme kultural dikembangkan dalam arena nasionalisme kemanusiaan. Hal ini dilakukan karena NU melihat bahwa ancaman kedaulatan Indonesia sebagai negara bangsa bukan hanya bersumber dari luar, tetapi bisa juga bersumbe dari dalam. Arus demokratisasi yang terjadi beriringan dengan meluasnya globalisasi sekonyong-konyong membuat ideologi berkurang keutamaannya dalam pergaulan internasional yang tidak terbatas. Akan tetapi, globalisasi memiliki dua sisi yang berbeda terhadap perkembangan suatu negara. Pada satu sisi globalisasi menyebabkan keruntuhan ideologi baik dalam skala global maupun lokal, namun pada sisi lain globalisasi telah memunculkan nasionalisme lokal maupun hadirnya ideologi transnasional yang berujung pada maraknya politik identitas. Politik identitas di Indonesia ditandai dengan munculnya gerakan islamis.

Gerakan Islamis merupakan gerakan politik Islam yang berupaya untuk mewujudkan penerapan ajaran Islam secara formal ke dalam kehidupan politik kenegaraan (Ariansyah \& Masyhur, 2020). Tujuan gerakan islamis dalam bidang politik kenegaraan ialah menerapkan ajaran Islam secara formal atau simbolisme Islam, misalnya penerapan syariat Islam ke dalam negara dan peraturan perundang-undangan melalui jalur politik. Usaha tersebut dilakukan dengan cara ikut serta secara legal formal dalam politik kenegaraan melalui pembentukan partai politik agar dapat berpartisipasi dalam proses politik formal maupun sebagai kelompok penekan dalam mempengaruhi kebijakan negara. Gerakan Islamis juga ditandai dengan munculnya gerakan Islam militan yang sebagian aksinya menggunakan cara-cara kekerasan dengan alasan memperjuangkan ajaran Islam (Faiqah \& Pransiska, 2018). Secara umum argumen pokok yang selalu dikembangkan oleh kelompok islamis dalam perjuangannya ialah mereka hanya berusaha untuk menciptakan umat Islam yang taat dalam beragama dengan melakukan jihad untuk menegakkan kebenarana dan mencegah kemungkaran, perlawanan terhadap sekularisme, pembelaan terhadap sesama Muslim dan pengawasan terhadap kinerja pemerintah.

Sebagai tameng terhadap gerakan islamis, paradigma nasionalisme kemanusiaan yang dipopulerkan oleh NU berkaitan erat dengan pola relasi antara Islam dan Negara yang ditumbuhkembangkan berdasarkan sikap toleransi dakam menyikapi berbagai realitas kemasyarakatan bangsa Indonesia yang multikultural. Dalam menyikapi keanekaragaman bangsa Indonesia sekaligus memperkenalkan Islam yang ramah dalam tata pergaulan berbangsa dan bernegara, maka NU selalu berusaha agar tradisi masyarakat diwarnai dengan muatan ajaran Islam agar dapat tumbuh sebagai modal sosial yang dapat menjadi perekat dalam mewujudkan ketahanan nasional. Ketahanan nasional dapat tercipta melalui pemanfaatan nilai-nilai luhur bangsa misalnya gotong royong, keseimbangan, kerjasama, sikap saling menghormati, dan kesederajatan dalam hubungan antar anak bangsa.

Nasionalisme kemanusiaan merupakan pemikiran dan pemahaman kebangsaan yang dikembangkan setelah Indonesia terbebas dari belenggu kolonialisme. Jika pada masa kolonial, nasionalisme terbentuk atas dasar kesadaran bersama untuk membebaskan diri dari belenggu penjajahan. Memasuki era pascakolonial, nasionalisme dibangun di atas kebersamaan untuk mewujudkan Indonesia sebagai negara yang maju, beradab dan berdaulat dalam pergaulan internasional. Menurut Tajudddin Noer Effendi, Nasionalisme kemanusiaan dibangun di atas prinsip, setiap bangsa memiliki kemampun dalam memberikan sumbangsih dalam 
memperkuat harkat dan martabat kemanusiaan, serta untuk mengembangkan nilai-nilai kemanusiaan sesuai dengan ciri khas dan sifat-sifat bangsa itu (Syarif, 2005). Lebih lanjut (Muhammad, 2020) menjelaskan bahwa nasionalisme kemanusiaa merupakan semangat mencintai Indonesia dengan cara membangun kerjasama antara manusia dengan mengabaikan latar belakang identitas keyakinan agama, suku, jenis kelamin, dan identitas budaya yang lain demi terwujudnya sebuah tatanan kehidupan yang saling menghargai dan menghormati keberadaannya masing-masing.

Kebangkitan Nasionalisme kemanusiaan merupakan sanggahan terhadap narasi besar yang menyatakan bahwa nasionalisme hanya menggema ketika ada ancaman dari luar (Suastika, 2013). Bagi NU penguatan nasionalisme di era refor-masi sangat penting karena realitas ke-bangsaan menunjukkan adanya penurunan moralitas masyarakat, memudarnya semangat cinta tanah air, terabaikannya identitas nasional, meningkatnya konflik bernuansa SARA, dan menguatnya isu disintegrasi bangsa yang dikhawatirkan akan merobek tenunan kebangsaan yang telah dirajut oleh para pendahulu bangsa (Azra, 1999). Ancaman terhadap keutuhan berbangsa dan bernegara juga berasal dari munculnya sikap intoleransi, yaitu sikap yang tidak menghormati hak-hak dasar setiap individu yang diatur oleh konstitusi negara.

Fenomena intoleransi mengalami penguatan menjelang pemilihan umum 2019 dan dampaknya berlanjut hingga saat ini. Intoleransi kerapkali mengklaim diri sebagai bentuk dari pelaksanaan ajaran agama, tetapi justru hal tersebut bertentangan dengan ajaran agama (Qodir, 2016). Di tengah maraknya berbagai aksi-aksi yang mengancam kebebasan asasi orang lain, Indonesia di bawah peran organisasi keagamaan yang moderat seperti NU harus mengarusutamakan nasionalisme kemanusiaan yang inklusif. Nasionalisme diwujudkan dengan cara memberikan pengakuan politik dan politik pengakuan terhadap martabat dan kebebasan individu maupun kesamaan hak atas berbagai kelompok budaya sehingga terwujud sebuah kerjasama yang beriringan secara damai dan produktif dalam bingkai Negara Kesatuan Republik Indonesia (Handayani, 2019). NU sebagai organisasi masyarakat Islam telah berusaha menunjukkan bahwa Islam sebagai agama dan peradaban tidak pernah mengajarkan untuk melakukan kekerasan. Islam diturunkan sebagai berkah bagi alam semesta yang membawa pesan keselamatan, perdamaian, keadilan, persaudaraan, dan cinta kasih. Islam ditampilkan oleh NU sebagai agama dan peradaban yang menghargai pluralisme yang memberikan kesempatan kepada semua kelompok suku, agama, ras, dan antargolongan untuk membangun sebuah masyarakat yang berkeadaban dan men-junjung tinggi emansipasi kemausiaan.

Perjuangan NU untuk mewujudkan nasionalisme kemanusiaan juga tidak dapat dilepaskan dari fenomena panggung politik di Indonesia. Reformasi yang dikenal sebagi era transisi demikrasi belum mampu menghadirkan pemerintahan yang dapat mewujudkan kesejahteraan rakyat yang merata baik di lingkungan perkotaan maupun perdesaan. Partai politik sebagai lokomotif demokrasi masih terbelenggu oleh praktik oligarki (Efriza, 2019). Oligarki telah menjadi faktor antara akan kemunculan praktik korupsi yang dilakukan oleh elite partai yang duduk dalam kekuasaan demi mempertahankan posisinya, sehingga kepentingan masyarakat banyak terabaikan sehingga rantai kemiskinan sulit untuk diputus. Maraknya praktik korupsi yang melibatkan elite partai politik menjadi sebuah pertanda akan kematian kepekaan sosial. Nalar kemanusiaan NU terusik, di tengah perjuangan bangsa Indonesia untuk terbebas dari belenggu kemiskinan, ternyata masih ada sekelompok orang yang berupaya untuk memperkaya diri sendiri, meskipun harus mengorbankan kepentingan rakyat $(\mathrm{H}$. Gunawan, 2018).

\section{Upaya Mewujudkan Nasionalisme Kemanusiaan}

Indonesia kontemporer harus dipandang dalam lensa krisis ideologi bernegara, tercerabutnya identitas kebangsaan dan melebarnya jarak sosial (AlJihad, 2018). Ditengah proses globalisasi yang melanda Indonesia saat ini, berbagai paham dari proses tersebut mulai merambah ke dalam masyarakat Indonesia dan cenderung memarginalkan bahkan menafikkan nilai budaya lokal yang banyak 
mengandung pesan-pesan moral sebagai identitas bangsa (Hilmi \& Pati, 2015). Pancasila sebagai ideologi negara secara kasat mata mulai ditinggalkan, dalam arti bahwa Pancasila sebagai filter nilai-nilai kehidupan sudah tidak efektif (Siswanto, 2017). Dalam kehidupan masyarakat, ketimpangan sosial yang ditandai dengan makin melebarnya demarkasi antara kelompok kaya dengan kelompok miskin turut menjadi keprihatinan bersama (Putri, Amar, \& Aimon, 2015).

Berpijak pada permasalahan yang melanda Indonesia pada saat ini, NU melihat bahwa persoalan tersebut bertolak pada memudarnya sandaran moral etis dan pedoman perilaku yang melekat pada perilaku sosial, ekonomi, politik, dan budaya pada tataran masyarakat awam maupun di kalangan elite (Bilfagih, 2018). Di tengah maraknya aneka ragam hambatan yang dihadapi oleh Bangsa Indonesia, NU tetap berdiri tegak menjadi bagian integral dari semangat kebangsaan. NU selalu menjadi mitra pemerintah dalam menjalankan amanah rakyat untuk melakukan kegiatan pembangunan di segala bidang demi mencapai kemaslahatan masyarakat. Semangat tersebut menjadikan NU tetap setia dalam menjaga keutuhan NKRI sebagai rumah besar bagi masyarakat Indonesia yang beranekaragam agama dan kebudayaan.

Usaha NU dalam menjaga keutuhan NKRI ditunjukkan dengan tekad untuk mewujudkan hidup bersama yang sesuai dengan harkat kemanusiaan (nasionalisme kemanusiaan). Sebagai sebuah konsep/ pemahaman dalam menata kehidupan berbangsa dan bernegara, nasionalisme kemanusiaan jika ditilik dalam perspektif teori fungsional yang diperkenalkan oleh Talcott Parsons maka dapat diurai dengan menggunakan kerangka AGIL, yaitu konsep tersebut memiliki fungsi adaptation (adaptasi), goal attainment (pencapaian tujuan), integration (integrasi), dan latency (pemeliharaan pola) (Nazsir, 2008). Nasionalisme kemanusiaan dalam perspektif adaptasi diharapkan dapat memunculkan kesadaran masyarakat dalam menghargai kemajemukan, sehingga dapat hidup dan menyesuaikan diri dengan lingkungan sosial yang masyarakatnya beranekaragam. Artinya, masyarakat yang kokoh berpegang teguh pada pandangan hidup demokratis harus dengan sendirinya teguh memelihara dan melindungi jaringan-jaringan multikuturalisme yang sudah terbangun dan mengembangkannya untuk suatu tujuan kebersamaan demi tegaknya NKRI. Dalam konteks pencapaian tujuan, yakni terwujudnya kemakmuran dan kesejahteraan rakyat yang berbasis pada Pancasila dan UUD 1945, maka nasionalisme kemanusiaan sebagai spirit bagi pemerintah dan masyarakat untuk bersinergi dalam pemenuhan kehidupan ekonomi. Prinsip ini mengandung makna penting untuk mendukung terealisasinya kehidupan demokratis. Ada pertanda langsung antara kesejahteraan, kemakmuran dan kehidupan demokratis (Madjid, 2009). Karena itu, NU memandang bahwa gagasan dan rancangan pembangunan yang berorientasi pada kepentingan masyarakat merupakan perwujudan nilai-nilai kemanusiaan universal.

Nasionalisme kemanusiaan dalam kaitannya dengan fungsi integrasi, secara politis bermakna sebagai upaya penyatuan berbagai kelompok sosial dan budaya dalam bingkai NKRI dalam mewujudkan sebuah identitas kebangsaan. Dalam mewujudkan integrasi nasional yang kuat, NU selalu mendakwahkan pentingnya menjaga kedaulatan dan keutuhan NKRI, serta menjaga dan memperkuat persatuan di tengah masyarakat yang majemuk dengan cara menanamkan dan mengimplementasikan sikap saling menghargai dan membangun dialog antar komponen warga negara (Farih, 2016) melalui dialog lintas agama maupun dialog lintas budaya. Adapun fungsi pemeliharaan pola yang terkait dengan nasionalisme kemanusiaan ialah menumbuhkan semangat kebangsaan berdasarkan prinsip humanisme yang telah ditegaskan dalam setiap ajaran agama, maupun dalam Pancasila sebagai ideologi negara. Pada kerangka ini, Pancasila ditempatkan sebagai landasan konstitusional dalam mengatur hubungan masyarakat dalam berbangsa dan bernegara, sedangkan ajaran agama, khususnya Islam ditempatkan sebagai landasan aqidah bagi pemeluknya.

Upaya memperkuat fungsi nasionalisme kemanusiaan sebagai landasan dalam menangkal paham radikal, NU telah menempuh berbagai langkah, sebagaimana yang dikatakan oleh Ahmad Ishomuddin dalam Kongres Umat Islam Indonesia VII tahun 2020 di Provinsi Bangka Belitung 
(Faizin, 2020). Pertama, penghargaan dan penghormatan kepada setiap warga negara untuk menganut agama dan berkeyakinan tanpa adanya unsur paksaan, diskriminasi dan segregasi. Kedua, pengakuan terhadap sistem politik yang sah dengan cara menghormati tatanan negara bangsa. Ketiga, mengakui keberadaan pemerintah yang sah sebagai hasil kesepakatan bersama sepanjang tidak melenceng dari prinsip dasar Pancasila dan UUD 1945. Keempat, mendukung keterlibatan Indonesia dalam tata pergaulan internasional dalam menjaga perdamaian dan ketertiban dunia.

\section{Implementasi Nasionalisme Kemanusiaan}

Dalam konteks Indonesia, berkembang pendapat yang meyakini bahwa negara merupakan sebuah institusi netral, yang tidak berpihak, berdiri di atas semua kelompok masyarakat, dan mengabdi kepada kepentingan bersama (Budiman, 2002). Anggapan tersebut dapat ditelusuri pada pernyataan-pernyataan yang pernah dilontarkan oleh Soekarno bahwa pendirian Negara Indonesia diperuntukkan bagi semua kalangan, bukan untuk kepentingan satu kelompok baik kelompok kaya maupun kelompok bangsawan (Dewantara, 2015). Demikian halnya yang sering disampaikan oleh Joko Widodo bahwa Bangsa Indonesia merupakan rumah besar bagi seluruh masyarakat tanpa mempertajam bedaan asal usul suku, agama, ataupun golongan (Agustina, 2017). Pernyataan tersebut kemudian dimaknai oleh sebagian kalangan bahwa setiap warga negara dijamin dan diberikan kebebasan untuk menunjukkan ekpresi dan aspirasi politiknya pada ranah publik dengan maksud sebagai upaya pengawalan terhadap pemerintah dalam menjalankan roda pemerintahan.

Pemberian dan jaminan kebebasan oleh negara yang dilindungi oleh konstitusi menjadi spirit bagi individu maupun kelompok untuk mendirikan partai politik maupun organisasi kemasyarakatan. Pada saat Indonesia memasuki era reformasi yang ditandai dengan berhentinya Soeharto dari jabatan Presiden Republik Indonesia pada Hari Kamis 21 Mei 1998, maka bermunculan organisasi kemasyarakatan maupun partai politik yang menggunakan simbolisme dan konsep-konsep agama, khususnya Islam, misalnya Front Pembela Islam dan Partai Keadilan Sejahtera. Kemunculan politik identitas dan penggunaan simbol-simbol agama dalam percaturan politik di Indonesia dianggap sebagai penguatan Islam politik dalam kontestasi di antara berbagai kelompok untuk meraih kekuasaan dan penafsiran Islam. Muncul pula penilaian dari kalangan nasionalis sekuler, bahwa menguatnya Islam politik merupakan bukti semakin masifnya tuntutan untuk menjadikan Indonesia sebagai negara Islam.

Kehadiran kelompok yang mengusung simbol-simbol Islam dalam menyampaikan aspirasi politiknya, terutama Front Pembela Islam seringkali menimbulkan keresahan dalam masyarakat. Kelompok ini marak melakukan aksi sweeping pada Bulan Ramadan, penyerangan terhadap rumah ibadah, tindakan persekusi dan main haikm sendiri terhadap kelompok maupun individu yang mereka anggap salah (Pujayanti \& Soeskandi, 2018). Menghadapi aksi-aksi seperti ini, pemerintah diperhadapkan pada posisi yang dilematis. Pemerintah, elite politik, aparat keamanan memandang FPI sebagai kelompok yang mempunyai posisi kuat, sehingga menindak mereka merupakan perlawanan terhadap Umat Islam.

Ketika negara, dalam hal ini pemerintah bersama aparat dinilai ragu dalam bersikap terhadap aksi-aksi bernuansa kekerasan yang ditampilkan oleh FPI, maka NU merasa perlu memberi penguatan kepada aparatur pemerintahan. Bagi NU, aksi kekerasan yang berujung pada kerugian material maupun kematian, merupakan tindakan yang tidak berperikemanusiaan dan bertolak belakang dengan prinsip-prinsip ajaran Islam. Oleh karena itu perlu adanya komitmen dan usaha dalam melawan radikalisme baik secara struktural maupun kultural. Jalur struktural ditempuh lewat berbagai peraturan dan konsistensi penegakannya. Sebaliknya, jalur kultural ditempuh dengan memberikan pemahaman kepada masyarakat mengenai Islam yang ramah dan implementasi nilai-nilai nasionalisme kemanusian pada segenap lapisan masyarakat.

Upaya NU dalam mengimplementasikan nilai-nilai nasionalisme kemanusiaan tentu berangkat dari prinsip dasar yang berkesesuaian dengan karakter masyarakat Indonesia yaitu tawazun (keseimbangan), tasamuh (toleran), tawasut (moderat), dan i'tidal (adil) dalam berbagai sektor kehidupan berbangsa dan bernegara (Cholili, 
2016). Prinsip dasar tersebut menunjukkan bahwa NU mampu menghadirkan sebuah proses penyesuaian dengan tuntutan tata kelola sebuah negara moderen, terciptanya tatanan kehidupan kenegaraan yang demokratis, harmonis, rukun, penghargaan terhadap keanekara-gaman, dan senantiasa bertumpu pada kerangka dasar keadilan sosial (Farih, 2019). Prinsip itu pula mencerminkan bahwa NU mengusung nasionalisme kemanusiaan untuk mempertahankan ikatan kebangsaan dalam mewujudkan masyarakat yang harmonis. NU berupaya untuk meneguhkan kembali komitmen kebangsaan yang mulai pudar akibat situasi krisis dan euforia reformasi yang berlebihan. Nasionalisme kemanusiaan sebagaimana yang digagas oleh Abdurrahman Wahid diimplementasikan dengan memperhatikan berbagai aspek.

\section{Ketauhidan}

Sebagai upaya dalam mencapai kemaslahatan dunia, Imam al-Mawardi menegaskan pentingnya posisi agama (Mahasin, 2020). Peran sosial agama sebagai faktor pemersatu bagi masyarakat adalah fungsi agama untuk mewujudkan ikatan bersama, baik antara individu sebagai bagian dari masyarakat maupun dalam kewajiban kemanusiaan yang mempersatukan mereka. Hal ini disebabkan nilai-nilai yang menopang sistem-sistem kewajiban kemanusiaan didukung bersama oleh kelompok keagamaan sehingga agama menjamin adanya permufakatan dalam masyarakat (Jamaludin, 2015). Manusia, baik sebagai individu maupun anggota masyarakat memerlukan kehadiran agama sebagai sebuah sistem nilai yang memiliki derivasi pada norma-norma masyarakat sebagai legitimasi dalam menata tingkah laku manusia (Amran, 2015).

Salah satu hal yang selalu berhubungan erat dengan agama, khususnya Agama Islam ialah tauhid. Secara umum, tauhid dipahami sebagai suatu basis kepercayaan Islam yang meliputi keyakinan terhadap Allah SWT beserta sifat-sifatnya, keyakinan terhadap malaikat, ruh, jin, kepercayaan terhadap kitab suci, kepercayaan terhadap nabi dan rasul, keyakinan akan adanya hari kiamat, takdir baik, takdir buruk, surga, neraka, dan syafaat (Siradj, 2010). Tauhid diartikan pula sebagai keyakinan terhadap keesaan Allah SWT, sehingga tidak ada yang patut disembah melainkan dia.

Dalam konteks nasionalisme

kemanusiaan, NU atas dasar paham Ahlussunnah wal Jamaah selalu menganjurkan kepada segenap warga negara Indonesia, khususnya kalangan umat Islam agar mengimplementasikan ajaran tauhid dengan memperhatikan lima aspek yaitu: (1) meyakini Allah sebagai Maha Pencipta agar terbebas dari ateisme (2) meyakini keesaan Allah agar terbebas dari syirik (3) meyakini bahwa Allah tidak ada yang menyerupai (4) meyakini bahwa Allah adalah tidaka ada yang mendahului (5) meyakini bahwa Allah merupakan pengatur kehidupan di muka bumi ini (Suhartono \& Faizah, 2017). Ketika manusia sudah bertauhid, maka dengan sendirinya tercipta sebuah pengakuan bahwa tidak ada yang memiliki kekuasaan penuh dalam menata kehidupan di muka bumi ini selain Allah. Manusia memiliki posisi yang sejajar di hadapan Allah sehingga tidak dibenarkan adanya aksi-aksi yang saling menindas dan merendahkan. Islam yang berlandaskan tauhid, sebagaimana yang ditegaskan dalam Piagam Madinah, sangat menghargai kebebasan beragama, kebebasan menyatakan pendapat di hadapan umum, jaminan keselamatan harta benda, dan larangan akan aksi-aksi kejahatan (Fajriah, 2019). Islam yang menekankan akan pentingnya kemanusiaan berbasis tauhid dipertegas oleh Abdurrahman Wahid bahwa ada lima jaminan dasar yang diberikan oleh Islam kepada individu dan masyarakat yakni: keselamatan fisik, keselamatan dalam beragama, keselamatan anggota keluarga dan keturunan, keselamatan harta benda, dan keselamatan pekerjaan (Wahid, 2007).

\section{Keadilan}

Salah satu anugerah Allah kepada manusia ialah Hak Asasi Manusia (Asiah, 2017). Hak Asasi Manusia diartikan sebagai konsep norma hukum dan yang menegaskan bahwa setiap individu mempunyai hak yang melekat terhadap dirinya yang berlaku tanpa batas ruang dan waktu. Salah satu hak dasar yang melekat pada manusia ialah hak untuk memeluk agama. Dalam Negara Kesatuan Republik Indonesia, hak untuk memeluk agama diatur dalam Pasal 29 UUD 1945 tentang kebebasan beragama. Konstitusi tersebut tentu berkonsekuensi bahwa negara harus memberikan perlakuan yang sama 
berdasarkan prinsip keadilan terhadap semua pemeluk agama yang bermukim di Negara Republik Indonesia.

Islam yang berdasarkan pada al-Quran dan Hadist Nabi menekankan pentingnya perlakukan yang adil terhadap seluruh umat manusia. Keadilan merupakan ketetapan fundamental yang dibawakan oleh ajaran Islam, baik yang bersifat individu, maupun dalam kehidupan kemasyarakatan dan kenegaraan. Seruan menegakkan keadilan setara dengan panggilan menegakkan kalimah Allah (Ibrahim, 2013). Dalam upaya menegakkan keadilan, terutama yang terkait dengan asas asas keadilan dalam politik Islam, maka NU mempertegas akan pentingnya asas perlindungan hak, kesamaan posisi di depan hukum, praduga tak bersalah dan hak membela diri, dan keadilan dalam merumuskan kebijakan. Terkait dengan asas perlindungan hak, negara secara jelas memberikan jaminan kepada setiap umat beragama dalam menjalankan ibadah. Sebagai bentuk dukungan terhadap kebijakan negara itu, maka dalam berbagai kesempatan kader NU selalu hadir dalam menjaga perayaan natal yang dilaksanakan di berbagai daerah di Indonesia.

Sikap NU dalam hal persamaan derajat di muka hukum ditunjukkan dengan dukungan penuh terhadap KPK dalam memberantas korupsi. Tercatat ada tiga kader NU yang terseret dalam pusaran korupsi, yaitu Imam Nachrawi, Muhammad Romahurmuziy, dan Suryadharma Ali. Akan tetapi, meskipun kadernya tersangkut dengan persoalan hukum dan dinyatakan terbukti bersalah, maka NU tetap mendukung aparat hukum dalam memberantas korupsi. Bagi NU, melawan korupsi merupakan perjuangan di jalan Allah dalam mencapai kemaslahatan bersama. Korupsi merupakan tindakan yang berseberangan dengan semangat nasionalisme, karena memperkaya diri sendiri dan kelompok, padahal semestinya kekayaan negara tersebut diperuntukkan untuk kemakmuran bersama, terutama kepada mereka yang masih berada dalam lingkaran kemiskinan.

Sebagai bentuk dalam penegakan keadilan, NU sangat menentang tindakan main hakim sendiri. NU sangat mengedepankan sikap praduga tak bersalah. Setiap individu tidak boleh menerima hukuman atas kesalahan yang masih disangkakan, sebelum melalui proses pengadilan. Jika suatu masalah masih dapat diselesaikan secara kekeluargaan, maka tidak perlu melalui proses pengadilan. NU selalu memberikan kesempatan kepada setiap individu untuk memberikan keteragan susulan atau tabayun. Kebiasaan tabayun merupakan ajaran Islam yang tidak lekang oleh zaman, terutama yang terkait dengan informasi yang berpotensi untuk memunculkan konflik di tengah masyarakat.

\section{Kesetaraan}

Prinsip kesetaraan yang dibangun oleh NU berangkat dari adanya komitmen bahwa setiap manusia memiliki posisi yang setara di hadapan Tuhan Yang Maha Esa. Kesetaraan digaungkan oleh NU untuk mencegah terjadinya diskriminasi, marjinalisasi, dan subordinasi dalam lingkungan masyarakat yang dikhawatir-kan akan berujung pada disintegrasi kebangsaan. Salah satu hal yang dikhawatirkan oleh NU dalam merusak rajutan kebangsaan ialah maraknya penggunaan kata kafir di ruang publik. Dalam doktrin Islam, kafir ditujukan terhadap individu-individu yang tidak memberikan pengakuan akan kerasulan Muhammad SAW (Maarif, 2017).

Menjelang pemilihan Gubernur DKI, penggunaan kata kafir semakin marak. NU menilai bahwa kata kafir telah mengalami pergeseran dari makna teologis menuju makna ideologis. Kata kafir lebih banyak dipergunakan oleh kelompok tertentu, misalnya FPI dan HTI untuk mempersekusi dan mengintimidasi pemeluk agama lain. Bahkan perbedaan dalam pilihan politik kerap kali kata kafir ini terlontar. Tidak jarang ungkapan kekafiran begitu mudah disematkan kepada mereka yang berbeda dalam hal pemahaman keagamaan, mazhab, dan organisasi keagamaan. Kondisi ini dikenal dengan istilah pengafiran di zaman pemikiran (Zaid, 2003), sebuah kondisi yang memanfaatkan agama sebagai alat untuk memberikan pembenaran tindakan kekerasan simbolik terhadap yang lain (Wibisono, 2015).

Fenomena tersebut dicermati oleh NU, sehingga pada perhelatan Konferensi Alim Ulama dan Musyawarah Nasional NU yang berlangsung pada tanggal 17 Februari-1 Maret 2019 dihasilkan Bahtsul Masail yang mengganti penggunaan kata kafir menjadi non-Muslim. Selain itu, NU menegaskan bahwa pemerintah atau negara tidak boleh 
memberikan vonis sesat kepada individu maupun kelompok keagaamaan tertentu. Pemerintah justru dihimbau agar memberikan pembinaan terhadap mereka yang menyimpang dari ajaran agamanya. Dalam konteks pergaulan berbangsa dan bernegara, mereka yang beragama di luar Islam tetap diakui sebagai penduduk negara yang mempunyai hak dan kewajiban setara dalam berbagai sektor kehidupan.

\section{Kebebasan Beragama}

Setelah Indonesia memasuki era reformasi selama dua dekade, negara ini mengalami berbagai dinamika dalam proses konsolidasi demokrasi. Dinamika yang dimaksud antara lain meningkatnya tindak kekerasan bernuansa SARA, aksi intoleransi, dan maraknya ujaran kebencian baik di jagad nyata maupun di jagad maya (Muharam, 2016). Arus prasangka etnis, sosial, ekonomis, dan keagamaan yang masih ada telah berwujud menjadi aneka konflik. Dari sisi kehidupan beragama, terdapat tiga ancaman yang membayangi persatuan dan kesatuan bangsa yaitu agresifitas sebagian pemeluk agama terhadap pemeluk agama yang lain, organisasi keagamaan yang lebih mengejar kuantitas daripada kualitas, dan disparitas sosial ekonomi antarpenganut agama (Ismail, 2019).

Kemunculan suasana yang disharmoni akibat konflik sosial yang bernuansa SARA sesungguhnya telah menodai prinsip kebebasan sebagai basis dasar kemanusiaan. Sebagai upaya untuk mewujudkan kehidupan sosial yang harmonis, maka NU menggelorakan kembali pentingnya pembebasan. Sejarah pembebasan dan penyelamatan kemanusiaan atau humanitas adalah ajaran pokok Islam sebagai agama dan peradaban. NU memberikan dukungan kepada negara dalam melaksanakan liberalisasi politik yang berarti masyarakat diberikan kebebasan untuk menentukan dan memilih keyakinannya (Qodir, 2011). Kebebasan dalam ajaran Islam merupakan hak setiap manusia yang berdampak positif bagi kelangsungan dan perkembangan pemikiran, sikap, dan keyakinan terhadap agama yang dianutnya. Dalam konteks kehidupan beragama serinng terjadi ketersinggungan antarpemeluk agama. Agar terhindar dari konflik bernuansa agama, maka setiap manusia harus melepaskan diri dari sikap memaksakan kehendak dan merasa agamanya paling benar. Islam memberi ruang terhadap hak-hak bagi penganut agama untuk menjalankan keyakinannya secara bebas (Musa, 2014).

Kultur NU dalam hal berkeyakinan dan beragama ditandai dengan apresiasi terhadap toleransi, kebebasan, dan megendepankan terjalinnya kerjasama yang bermutu. Pengakuan terhadap Pancasila sebagai ideologi negara merupakan bukti bahwa NU sangat menghargai prinsip kebebasan. Kebebasan di Indonesia berlaku untuk semua, baik di kalangan mayoritas maupun minoritas. Perjuangan NU dalam menegakkan kebebasan merupakan kewajiban keumatan, sehingga Islam sebagai mayoritas harus tetap bersikap rendah hati dan memberikan perlindungan kepada kalangan minoritas.

\section{Kearifan tradisi}

Kearifan yang terdapat dalam nilainilai tradisional dari setiap suku bangsa di Negara Indonesia merupakan khasanah budaya yang menunjukkan bahwa negara ini merupakan negara yang multikultur. Kearifan tradisi sebagai bagian dari kebudayaan merupakan upaya masyarakat dalam menjawab setiap tantangan seiring perkembangan zaman (Gunawan, 2019). NU memandang bahwa kebudayaan tidak bertentangan dengan agama secara internal. Sebaliknya, kebudayaan dapat dimanfaatkan sebagai instrumen dalam melaksanakan keyakinan agama secara kaffah (Najib \& Fata, 2020), dalam arti bahwa agama, khususnya Islam dapat memberikan apresiasi dan afirmasi terhadap kebudayaan yang berkembang di Indonesia. Dalam konteks historis, nasionalisme dan Islam memiliki keterkaitan erat dengan proses penyebaran agama Islam di Indonesia yang banyak mengakomodasi tradisi yang ada pada masyarakat setempat, sehingga pada akhirnya Islam menjadi bagian integral dari budaya Indonesia (Azra, 2011).

Kearifan tradisi sangat diperlukan oleh Indonesia yang tidak dapat menghindarkan diri dari globalisasi. Dalam memberdayakan kearifan tradisi, NU telah berusaha dengan melakukan pembinaan dan pembentukan nilai karakter kebangsaan dan keumatan melalui pendidikan, terutama di pondok pesantren. Pembentukan karakter merupakan proses atau usaha secara sadar dalam menggali, menemukan, membangun, dan memperkuat secara berkelanjutan nilai-nilai budaya domestik Nusantara sebagai basis 
nilai dalam tata pergaulan (Ilahi, 2012). Ulama, cendekiawan, dan kaum intelektual dari kalangan NU dikenal sebagai sosok yang bijaksana dalam menyikapi pluralitas budaya dan kearifan tradisi yang ada pada masyarakat Indonesia. Melalui lembaga pendidikan yang dikelola oleh NU, mereka terus berkhikmat menyebarkan ajaran Islam yang penuh rahmat dan menjadikan kearifan lokal sebagai instrumen dakwah.

Perhatian NU dalam melestarikan kearifan tradisi tercermin dari kaidah fiqih yang mereka populerkan yaitu mempertahankan nilai-nilai lama yang baik dan menerapkan nilai-nilai baru yang lebih baik. Salah satu lembaga di bawah naungan NU yang bergelut dalam melestarikan budaya ialah Lembaga Seni dan Budaya Muslimin Indonesia (Lesbumi). Kehadiran Lesbumi diharapkan untuk membina manusia Muslim yang bertakwa dan berbudi luhur serta memiliki pengetahuan yang luas untuk mengelola berbagai keanekaragaman budaya Indonesia. Lesbumi memberikan alternatif dalam berkesenian dengan membuka peluang bagi unsur religi (Islam) setara dengan kebudayaan dalam bingkai seni dan budaya dan meminimalisasi persaingan yang bersifat politis. Fenomena ini memperkuat pandangan (Woodward, 2007) bahwa agama dalam perspektif budaya memberi sumbangsih yang besar terhadap penjagaan agama agar tetap selaras dengan kondisi zaman yang terus berubah sehingga hasilnya pada pemecahan masalah keagamaan yang dapat diterima dan memiliki arti secara kultural untuk problematika sosial kemasyarakatan.

\section{KESIMPULAN}

Indonesia sebagai sebuah bangsa yang berdaulat telah berusia 75 tahun sejak 17 Agustus 1945. Indonesia dibangun atas dasar nasionalisme dan kesepakatan dari berbagai elemen di belahan bumi Nusantara yang terdiri atas berbagai macam suku, agama, ras dan antar golongan. Kesepakatan berbagai bangsa di Nusantara untuk bernaung dalam sebuah negara yang dikenal dengan Negara Kesatuan Republik Indonesia diperkuat dengan menjadikan Pancasila sebagai dasar negara. Nasionalisme yang telah tercipta sejak zaman penjajahan terus menjadi spirit dalam melaksanakan pembangunan di segala bidang ketika memasuki alam kemerdekaan. Akan tetapi usaha untuk melaksanakan pembangunan demi mencapai kesejahteraan dan kemakmuran rakyat terusik dengan hadirnya paham transnasional yang dipopulerkan oleh Hizbut Tahrir Indonesia (HTI) dan tindakan kekerasan atas nama agama yang dipraktekkan oleh Front Pembela Islam (FPI). Gejala ini disikapi oleh NU sebagai organisasi kemas-yarakatan dengan menyuarakan kembali bahwa NKRI merupakan bentuk final dan Pancasila selaras dengan ajaran Islam.

Usaha dalam rangka menjaga NKRI sebagai bangsa yang berdaulat dalam melaksanakan pembangunan berdasarkan Pancasila, maka NU menggagas nasionalisme kemanusiaan, yaitu semangat kebangsaan yang dibangun atas dasar kemanusiaan, dalam arti bahwa semua anak bangsa dari berbagai suku, agama, ras, dan antar golongan memiliki hak untuk hidup di negara ini, sekaligus berkewajiban untuk mempertahankan NKRI dari berbagai ancama yang datang dari negara lain maupun dari dalam negeri. Dalam menegakkan nasionalisme kemanusiaan, maka NU merumuskan tiga model persaudaraan yaitu persaudaraan umat Islam, persaudaraan sebangsa dan setanah air, dan persaudaraan sesama umat manusia.

\section{DAFTAR PUSTAKA}

Agustina, L. (2017). Pemikiran Presiden Joko Widodo Dalam Pidato Sambutan (Thought the President Joko Widodo in a Greeting Speech). Jurnal Bahasa, Sastra Dan Pembelajarannya (JBSP), 7(1), 80-94. Retrieved from https://ppjp.ulm.ac.id/journal/index.php /jbsp/article/viewFile/3769/3410

Al-Jihad, R. S. (2018). Pancasila Ideologi Dunia: Sintesis Kapitalisme, Sosialisme, dan Islam. Ciputat: Alvabet.

Amran, A. (2015). Peranan Agama Dalam Perubahan Sosial Masyarakat. HIKMAH: Jurnal Ilmu Dakwah Dan Komunikasi Islam, 2(1), 23-39. Retrieved from http://repo.iainpadangsidimpuan.ac.id/269/1/Ali Amran.pdf

Ariansyah, R., \& Masyhur, M. (2020). Identitas Agama dan Pola Gerakan Sosial (Studi Kasus Front Pembela Islam 
Di Kota Palembang). Ampera: A Research Journal on Politics and Islamic Civilization, 1(1), 49-60. Retrieved from http://jurnal.radenfatah.ac.id/index.php/ Ampera/article/view/5206/2886

Asiah, N. (2017). Hak Asasi Manusia Perspektif Hukum Islam. DIKTUM: Jurnal Syariah Dan Hukum, 15(1), 5566. Retrieved from http://ejurnal.stainparepare.ac.id/index. php/diktum/article/view/425

Azra, A. (1999). Menuju Masyarakat Madani: Gagasan, Fakta, dan Tantangan. Bandung: Remaja Rosdakarya.

Azra, A. (2011). Nasionalisme, Etnisitas, dan Agama di Indonesia: Perspektif Islam dan Ketahanan Budaya. In T. J. Lan \& M. A. Manan (Eds.), Nasionalisme dan Ketahanan Budaya di Inodnesia: Sebuah Tantangan. Jakarta: Yayasan Obor Indonesia.

Bilfagih, T. (2018). Islam Nusantara; Strategi Kebudayaan NU di Tengah Tantangan Global. Aqlam: Journal of Islam and Plurality, 1(2).

Budiman, A. (2002). Teori Negara: Negara, Kekuasaan, dan Ideologi (3rd ed.). Jakarta: Gramedia.

Cholili, M. S. (2016). Toleransi Beragama (Studi Konsep Tawasut, I'tidal, Tawazun, dan Tasammuh) Sebagai Upaya Resolusi Konflik pada Masyarakat Perumahan Giri Pekukuhan Asri Mojosari. At-Tahdzib: Jurnal Studi Islam Dan Muamalah, 4(2), 144-154. Retrieved from http://ejournal.kopertais4.or.id/mataram an/index.php/tahdzib/article/view/2911

Dewantara, A. W. (2015). Pancasila Sebagai Pondasi Pendidikan Agama Di Indonesia. $\quad$ CIVIS,$\quad 5(1 /$ Januari). Retrieved from http://journal.upgris.ac.id/index.php/civ is/article/view/626

Efriza, N. F. N. (2019). Eksistensi Partai Politik Dalam Persepsi Publik [The Existence of The Political Parties in Public Perception]. Jurnal Politica Dinamika Masalah Politik Dalam Negeri Dan Hubungan Internasional, 10(1), 17-38. Retrieved from http://jurnal.dpr.go.id/index.php/politica /article/view/1314

Faiqah, N., \& Pransiska, T. (2018). Radikalisme Islam Vs Moderasi Islam:
Upaya Membangun Wajah Islam Indonesia Yang Damai. Al-Fikra: Jurnal Ilmiah Keislaman, 17(1), 33-60. Retrieved from http://ejournal.uinsuska.ac.id/index.php/al-

fikra/article/view/5212

Faizin, M. (2020). Empat Hal Prinsip untuk Wujudkan Nasionalisme menurut Kiai Ishom. Retrieved February 3, 2021, from NU Online website: https://www.nu.or.id/post/read/117224/ empat-hal-prinsip-untuk-wujudkannasionalisme-menurut-kiai-ishom

Fajriah, N. (2019). Kerukunan Umat Beragama: Relevansi Pasal 25 Piagam Madinah Dan Pasal 29 UUD 1945. Substantia: Jurnal Ilmu-Ilmu Ushuluddin, 21(2), 162-169. Retrieved from https://jurnal.arraniry.ac.id/index.php/substantia/article /view/5525

Farih, A. (2016). Nahdlatul Ulama (NU) dan Kontribusinya dalam Memperjuangkan Kemerdekaan dan Mempertahankan Negara Kesatuan Republik Indonesia (NKRI). Walisongo: Jurnal Penelitian Sosial Keagamaan, 24(2), 251-284. Retrieved from https://journal.walisongo.ac.id/index.ph $\mathrm{p} /$ walisongo/article/view/969

Farih, A. (2019). Konsistensi Nahdlatul Ulama' dalam Mempertahankan Pancasila dan Kedaulatan Negara Kesatuan Republik Indonesia di tengah Wacana Negara Islam. Jurnal Politik Walisongo, 1(1). Retrieved from https://journal.walisongo.ac.id/index.ph $\mathrm{p} / \mathrm{JPW} /$ article/view/2026/pdf

Gunawan, A. (2019). Tradisi Upacara Perkawinan Adat Sunda (Tinjauan Sejarah dan Budaya di Kabupaten Kuningan). Jurnal Artefak, 6(2), 71-84.

Gunawan, H. (2018). Korupsi Dalam Perspektif Hukum Islam. Yurisprudentia: Jurnal Hukum Ekonomi, 4(2), 182-199. Retrieved from http://jurnal.iain-

padangsidimpuan.ac.id/index.php/yuris prudentia/article/view/1506

Handayani, S. A. (2019). Nasionalisme di Indonesia: Adaptasi Atau Transplantasi. Jurnal Historia, 1(2), 154-170. Retrieved from https://jurnal.unej.ac.id/index.php/JH/ar ticle/view/6917

Hilmi, R., \& Pati, D. S. T. A. I. (2015). Moral 
dan Identitas Nasional Dalam Era Globalisasi. Al-Burhan, 7(2), 40. Retrieved from http://www.staipati.ac.id/jurnal/vol_7_n o_2_Juli_2015.pdf\#page $=44$

Huntington, S. P. (1996). Gelombang Demokratisasi Ketiga (Terj. Asril Marjohan). Jakarta: Grafiti Pers.

Ibrahim, M. S. (2013). Demi Islam, Demi Indonesia. Jakarta: Dian Rakyat.

Ilahi, M. T. (2012). Nasionalisme Dalam Bingkai Pluralitas Bangsa: Paradigma Pembangunan dan Kemandirian Bangsa. Yogyakarta: Ar-Ruzz Media.

Ismail, F. (2019). Islam, Konstitusionalisme, dan Pluralisme: Memperkuat Fondasi Kebangsaan dan Merawat Relasi Kebinekaan. Yogyakarta: IRCiSoD.

Jamaludin, A. N. (2015). Agama dan Konflik Sosial: Studi Kerukunan Umat Beragama, Radikalisme, dan Konflik Antarumat Beragama. Bandung: Pustaka Setia.

Joebagio, H. (2016). Membaca Politik Islam Pasca Reformasi. Agastya: Jurnal Sejarah Dan Pembelajarannya, 6(01), 1-8. Retrieved from https://core.ac.uk/download/pdf/229500 402.pdf

Karim, S. (2012). Islamisme dan Demokratisasi di Indonesia Pasca Reformasi: Analisis Sosio-Politik. Sulesana: Jurnal Wawasan Keislaman, $7(2)$, 149-159. Retrieved from https://core.ac.uk/download/pdf/234751 504.pdf

Kuntowijoyo. (2005). Pengantar Ilmu Sejarah. Yogyakarta: Bentang Pustaka.

Kusmayadi, Y. (2017). Politik Luar Negeri Republik Indonesia Pada Masa Konfrontasi Indonesia-Malaysia Tahun 1963-1966. Jurnal Artefak, 4(1), 23-34.

Maarif, N. H. (2017). Islam Mengasihi, Bukan Membenci. Bandung: Mizan.

Madjid, N. (2009). Cendekiawan dan Religiusitas Masyarakat (Cetakan Ke). Jakarta: Dian Rakyat.

Mahasin, A. (2020). Korban Tabrak Lari Hawa Nafsu Sendiri. Jakarta: PT Elex Media Komputindo.

Masruhan, M. (2009). Pemikiran Kyai NU tentang Relasi Agama dan Negara. AlQanun: Jurnal Pemikiran Dan Pembaharuan Hukum Islam, 12(1), 78105. Retrieved from http://jurnalfsh.uinsby.ac.id/index.php/q anun/article/view/150/136

Muhammad, H. (2020). Islam yang Mencerahkan dan Mencerdaskan: Memikirkan Kembali Pemahaman Islam Kita. Yogyakarta: Ircisod.

Muharam, M. (2016). Konservatisme dan Intoleransi Agama Pada Era Reformasi di Indonesia. Trisula, 2(2), 5.

Musa, A. M. (2014). Membumikan Islam Nusantara: Respon Islam Terhadap IsuIsu Aktual. Jakarta: Serambi Ilmu Semesta.

Najib, M. A., \& Fata, A. K. (2020). Islam Wasatiyah dan Kontestasi Wacana Moderatisme Islam di Indonesia. Jurnal Theologia, 31(1), 115-138. Retrieved from

https://journal.walisongo.ac.id/index.ph $\mathrm{p} /$ teologia/article/view/5764/pdf

Nazsir, N. (2008). Teori-Teori Sosiologi. Bandung: Widya Padjadjaran.

Pujayanti, N., \& Soeskandi, H. (2018). Pelaku Persekusi dan Tindakan Main Hakim Sendiri. Mimbar Keadilan, 14(28). Retrieved from http://jurnal.untagsby.ac.id/index.php/mimbarkeadilan/art icle/view/1784

Putri, Y. E., Amar, S., \& Aimon, H. (2015). Analisis Faktor-Faktor Yang Mempengaruhi Pertumbuhan Ekonomi Dan Ketimpangan Pendapatan Di Indonesia. Jurnal Kajian Ekonomi, 3(6). Retrieved from http://ejournal.unp.ac.id/index.php/ekon omi/article/view/5348/4227

Qodir, Z. (2011). Sosiologi Agama: Esai-Esai Agama di Ruang Publik. Yogyakarta: Pustaka Pelajar.

Qodir, Z. (2016). Kaum Muda, Intoleransi, dan Radikalisme Agama. Jurnal Studi Pemuda, 5(1), 429-445. Retrieved from https://jurnal.ugm.ac.id/jurnalpemuda/a rticle/view/37127/21856

Rahmat, M. I. (2018). Islamisme di Era Transisi Demokrasi: Pengalaman Indonesia dan Mesir. Yogyakarta: LKiS.

Saputra, I. (2019). Resolusi Jihad: Nasionalisme Kaum Santri Menuju Indonesia Merdeka. Jurnal Islam Nusantara, 3(1), 205-237. Retrieved from

https://jurnalnu.com/index.php/as/articl e/view/128

Sarman, M. (2018). Meretas Radikalisme Menuju Masyarakat Inklusif. 
Yogyakarta: LKiS

Setialaksana, N. (2017). Peranan Badan Penyelidik Usaha-Usaha Persiapan Kemerdekaan Indonesia (BPUPKI) 1945 Dalam Proses Menuju Kemerdekaan Indonesia. Jurnal Artefak, 4(2), 109-118.

Siradj, S. A. (2010). Tauhid Dalam Perspektif Tasawuf. ISLAMICA: Jurnal Studi Keislaman, 5(1), 152-160. Retrieved from

http://islamica.uinsby.ac.id/index.php/is lamica/article/view/105

Siswanto, S. (2017). Transformasi Ideologi Pancasila: Menjaga Identitas keIndonesiaan vs Pengaruh Global. Jurnal Penelitian Politik, 14(1), 55-68. Retrieved from http://ejournal.politik.lipi.go.id/index.p hp/jpp/article/view/687/492

Suastika, I. N. (2013). Nasionalisme Dalam Perspektif Postmodernisme, Poststrukturalisme Dan Postkolonialisme. Media Komunikasi FPIPS, 11(1). Retrieved from https:/ejournal.undiksha.ac.id/index.ph $\mathrm{p} / \mathrm{MKFIS} /$ article/view/452

Suhartono, S., \& Faizah, N. (2017). Konsep Aqidah Ahlus Sunnah Wal Jamaah Dan Pembinaannya Dalam Pendidikan Agama Islam Menurut Syaikh Abdul Qodir Al-Jailani. Al-I'tibar: Jurnal Pendidikan Islam, 4(1), 15-34. Retrieved from http://journal.stkipnurulhuda.ac.id/inde x.php/JPIA/article/view/189

Syarif, S. K. (2005). Merajut Manajemen Negara dalam BingkaiNasionalismeHumanis. UNISIA, 25(3). Retrieved from https://journal.uii.ac.id/Unisia/article/vi ew/5437

Wahid, A. (2007). Islam Kosmopolitan: NilaiNilai Indonesia dan Transformasi Kebudayaan. Jakarta: Wahid Institute.

Wibisono, M. Y. (2015). Agama, Kekerasan dan Pluralisme dalam Islam. Kalam, 9(2), 187-214. Retrieved from http://ejournal.radenintan.ac.id/index.ph p/KALAM/article/view/328

Woodward, M. R. (2007). Islam, Humanisme, dan Etika: Implementasinya dalam Indonesia Kontemporer. In Islam dan Humanisme: Aktualisasi Humanisme Islam di Tengah Krisis Humanisme Universal. Yogyakarta: Pustaka Pelajar.
Zaid, N. H. A. (2003). Teks, Otoritas, Kebenaran. Yogyakarta: LKiS. 